\title{
Hemophagocytic Lymphohistiocytosis in Autopsied Adults: Clinical, Laboratory and Immunohistochemical Evaluation for CD68 and CD57. Case Report and Literature Review
}

\section{Linfohistiocitose Hemofagocítica em Adultos Autopsiados: Avaliação Clínica, Laboratorial e Imunohistoquímica para CD68 e CD57. Relato de Caso e Revisão de Literatura}

\author{
Márcus Otávio Silva de Campos Menêses ${ }^{\mathrm{a}}$; Renata Margarida Etchebehere ${ }^{\mathrm{b}}$; Márcia Fernandes de Araújo ${ }^{\mathrm{b}}$; Ana Cristina \\ da Rocha Duque ${ }^{\text {b; Denise Bertulucci Rocha Rodrigues }}$; Sanívia Aparecida de Lima Pereira*c \\ aUniversity of Uberaba, Undergraduate Medical Student. MG, Brazil. \\ ${ }^{b}$ Federal University of Triângulo Mineiro, Pathology Department. MG, Brazil. \\ 'University of Uberaba, Laboratory of Biopathology and Molecular Biology. MG, Brazil. \\ ${ }^{\mathrm{d}}$ Federal University of Triângulo Mineiro, Cefores. MG, Brazil. \\ *E-mail: sanivia.pereira@uniube.br \\ Recebido em: 20/08/2019; Aprovado em: 22/11/2019
}

\begin{abstract}
Hemophagocytic lymphohistiocytosis (HLH) is a rare, usually fatal and underdiagnosed autoimmune-activated disease. The present study aimed to perform a macroscopic, histopathological and immunohistochemical evaluation for CD68 and CD57 in organs of autopsied adults with HLH. A total of 604 autopsy reports were analyzed, and all the patients that filled the diagnostic criteria for HLH $(n=2)$ were selected. These patients were 18 and 37 years old. Were evaluated both clinical and autopsy reports and performed histopathological and immunohistochemical analysis of the liver and spleen. Both patients filled the diagnostic criteria for HLH, as well as presented common signs and symptoms of this disease, such as chills, abdominal pain, diaphoresis, and jaundice. Hemophagocytosis was observed in the spleen, bone marrow, and lymph nodes of the two patients at autopsy. Immunostaining in the liver and spleen of both patients was mainly severe for CD68, and predominantly mild for CD57, indicating a decrease in NKC numbers and an increase in the number of macrophages, respectively. This was the first study to evaluate CD57 and CD68 in autopsies of adults with HLH. Thus, more studies are required, not only to better elucidate the pathogenetic mechanisms involved in the secondary HLH, but also to disseminate the results in the clinical environment, contributing to the early diagnosis and treatment with consequent reduction of mortality rate.
\end{abstract}

Keywords: Autoimmune Diseases. Histiocytosis. Biomarkers.

\section{Resumo}

A Linfohistiocitose Hemofagocítica (HLH) é uma doença autoimune rara, geralmente fatal e subdiagnosticada. Este estudo tem como objetivo realizar avaliação macroscópica, histopatológica e imunohistoquímica para CD68 e CD57 em órgãos de pacientes adultos com HLH submetidos a autópsia. Um total de 604 laudos de autópsias foram analisados e todos os pacientes que preencheram os critérios diagnósticos para HLH $(n=2)$ foram selecionados. Esses pacientes tinham 18 e 37 anos de idade. Foram analisados tanto os prontuários quanto os laudos de autópsia, bem como foram realizadas análises histopatológicas e imunohistoquímicas do figado e baço dos pacientes. Ambos preencheram os critérios diagnósticos para HLH e apresentarem sinais e sintomas comuns da doença, como calafrios, dor abdominal, sudorese e icterícia. A hemofagocitose foi observada no baço, medula óssea e linfonodos dos dois pacientes na autópsia. A imunohistoquímica do fígado e do baço de ambos os pacientes demonstrou imunomarcação acentuada para CD68 e predominantemente discreta para CD57, que indicam diminuição do número de NKC e aumento do número de macrófagos, respectivamente. Este foi o primeiro estudo a avaliar o CD57 e CD68 em autópsias de adultos com HLH. Assim, mais estudos são necessários, não apenas para melhor elucidar os mecanismos patogenéticos envolvidos na HLH secundária, mas também para disseminar os resultados no ambiente clínico, contribuindo para o diagnóstico e tratamento precoces com consequente redução da taxa de mortalidade.

Palavras-chave: Doenças Autoimunes. Histiocitose. Biomarcadores.

\section{Introduction}

Hemophagocytic lymphohistiocytosis (HLH) is a rare and usually fatal autoimmune-activated disease. ${ }^{1}$ Mortality rate can exceed $50 \% .^{2}$ The epidemiology of HLH is difficult to determine because it is generally undiagnosed. ${ }^{1}$ However, the estimated incidence is $1 / 50,000-3.6 / 1,000,000$, without gender predilection. ${ }^{1,3}$

There are two different forms of HLH, primary HLH, and secondary or reactive HLH. The primary HLH is a sporadic familial autosomal recessive disease characterized by mutations in the perforin (PRF1) gene, Munc-13-4 (UNC13D) gene, syntaxin 11 (STX11) gene, gene encoding syntaxin binding protein 2 (STXBP-2), SH2 domain-containing protein 1A (SH2D1A), and X-linked inhibitor of apoptosis protein (XIAP) ${ }^{4-7}$ The secondary or reactive HLH is usually observed in adults and is associated with early stages of another disease such as infectious and malignant diseases, ${ }^{8}$ chronic rheumatic diseases, ${ }^{9}$ and juvenile dermatomyositis. ${ }^{10}$

HLH is a hyper-inflammatory condition resulting from various disorders that affect macrophages, lymphocytes, and natural killer cells (NKC), ${ }^{11}$ unleashing an excessive proliferation of those cells in response to the triggering agent. ${ }^{5,11,12}$ It is believed that there is an inappropriate control 
of cellular immune response and a decreased cytotoxic activity of NKC and CD8+ T cells. Consequently, antigen removal process is impaired, which stimulates the proliferation and activation of T cells. ${ }^{13}$ Activated CD8+ T cells produce large amounts of interferon (IFN) that stimulates proliferation and activation of macrophages. Macrophages, on the other hand, release large amounts of inflammatory cytokines such as interleukin (IL)-2, IL-6, IL-1, IL-10, IL-12, tumor necrosis factor (TNF)-alpha and granulocyte-macrophage colonystimulating factor (GM-CSF), resulting in a cytokine storm and excessive inflammatory response. ${ }^{13-15}$

The microscopic evaluation shows that the proliferation of histiocytes usually occurs to all hematopoietic organs ${ }^{12}$ with subsequent phagocytosis of erythrocytes by macrophages, forming hemosiderin in the bone marrow, spleen and lymph nodes. ${ }^{5,15}$

The proliferation of $\mathrm{T}$ cells and macrophages in HLH causes sudden onset fever, hepatosplenomegaly, lymphadenopathy, pancytopenia, hepatic dysfunction, ${ }^{16-18}$ fatigue, weight loss, multiple organ failure, and disseminated intravascular coagulation (DIC). ${ }^{19}$ Several patients have a fulminant progression, with mortality rates ranging from $22 \%$ to $59 \%$. Fatal cases usually occur within 4 to 8 weeks due to multiple organ failure, bleeding and sepsis. ${ }^{17}$

Although some studies have already performed an immunohistochemical evaluation for CD57 (NKC marker) in $\mathrm{HLH},{ }^{19,20}$ they were performed only using the serum of patients. Similarly, there has not been found any studies that evaluated CD68 immunostaining (macrophage marker) in autopsies of adults with HLH.

The objective of this study was to perform a macroscopic, histopathological, and immunohistochemical evaluation for CD68 and CD57 in organs of adult autopsied patients with $\mathrm{HLH}$, associating the findings with the clinical and laboratory aspects.

\section{Material and Methods}

\subsection{Patient selection}

After approval by the research ethics committee of the University of Uberaba (UNIUBE) (CAAE: 56243916.9.0000.5154 - approval date December 12, 2016), we analyzed all autopsy reports performed by the Department of General Pathology of Federal University of Triangulo Mineiro (Universidade Federal do Triângulo Mineiro), Uberaba, Minas Gerais, Brazil, from April 22, 1982 to June $18,2015(\mathrm{n}=604)$. The individuals that underwent autopsy were aged between 17 to 105 years old. These individuals came from the following departments: clinical medicine $(\mathrm{n}=346)$; infectious diseases $(\mathrm{n}=96)$; surgical clinic $(\mathrm{n}=$ $95)$; intensive care $(n=45)$; and emergencies $(n=22)$. We selected the patients identifying the diagnostic criteria for
HLH on medical records, which had laboratory and clinical data, and during microscopic analysis of all organs. Active hemophagocytosis research was performed in all 604 cases and all the patients with HLH $(\mathrm{n}=2)$ were selected: patient 1 ( $\mathrm{P} 1,37$-year-old, male) and patient 2 (P2, 18-year-old, male).

\subsection{Clinical records evaluation}

Medical records evaluation of the two patients was performed not only to collect clinical evolution data but also to collect data related to results of laboratory tests.

\subsection{Histochemical analysis}

After evaluation of the clinical records of both patients, a histochemical analysis was performed on slides containing liver, spleen, lymph nodes, and bone marrow sections filed at the time of the autopsy. During this evaluation, we tried to identify pathological processes such as hemorrhage, hyperplasia, steatosis, fibrosis, inflammation, and hemosiderin. Pathological processes were classified as present or absent.

\subsection{Immunohistochemical analysis}

The immunohistochemical evaluation was performed only in the liver and spleen, as they were the only organs that still had fragments left.

For immunohistochemical reactions, the following primary antibodies were used: anti-CD57 for natural killer cells (Zeta Corporation, CA, USA, 1:200 dilution), and antiCD68 for monocytes, macrophages and Langerhans cells (Bio SB, Santa Barbara, CA, USA, 1:200 dilution). For antibody detection, a polymer detection system (Spring, Pleasanton, CA, USA) was used (according to the label).

All slide fields were observed using a common light microscope (BIOVAL, Valencia, Spain). Slides that underwent immunohistochemistry were semi-quantitatively scored as follows: absent ( 0 cells marked per field); mild: (up to 33\% cells stained per field); moderate (33-66\% cells stained per field); and severe ( $>66 \%$ stained cells per field). ${ }^{24} \mathrm{~A}$ single examiner performed histochemical and immunohistochemical analyses blindly.

\section{Results and Discussion}

\subsection{Clinical evolution and laboratory findings of P1}

A 37-year-old male patient was admitted complaining fever for three months $\left(39.5{ }^{\circ} \mathrm{C}\right)$ accompanied by chills, diaphoresis, pallor, edema of the lower limbs, weight loss, adynamia, ascites, and hepatosplenomegaly with abdominal distension (Table 1). 
Table 1 - Diagnostic criteria for HLH of both patients 1 (P1) and $2(\mathrm{P} 2)$

\begin{tabular}{|c|c|c|}
\hline Diagnostic criteria for HLH* & P1 & $\mathrm{P} 2$ \\
\hline $\begin{array}{l}\text { Molecular diagnosis of HLH or X-linked } \\
\text { lymphoproliferative syndrome (XLP) }\end{array}$ & $D A^{* *}$ & $D A^{* *}$ \\
\hline \multicolumn{3}{|l|}{ Or at least 3 of $4:$} \\
\hline a. Fever & + & + \\
\hline b. $\quad$ Splenomegaly & + & + \\
\hline $\begin{array}{l}\text { c. Cytopenias (minimum } 2 \text { cell lines } \\
\text { reduced) }\end{array}$ & + & + \\
\hline d. Hepatitis & + & + \\
\hline \multicolumn{3}{|l|}{ And at least 1 of 4: } \\
\hline a. Hemophagocytosis & + & + \\
\hline b. $\quad \uparrow$ Ferritin & $D A * *$ & $D A^{* *}$ \\
\hline c. $\uparrow$ sIL2R $\alpha$ (age based) & $D A^{* *}$ & $D A^{* *}$ \\
\hline $\begin{array}{l}\text { d. Absent or very decreased } \\
\text { NK function }\end{array}$ & $D A^{* *}$ & $D A^{* *}$ \\
\hline \multicolumn{3}{|l|}{$\begin{array}{l}\text { Other results supportive of HLH } \\
\text { diagnosis: }\end{array}$} \\
\hline a. $\quad$ Hypertriglyceridemia & $D A^{* *}$ & $D A^{* *}$ \\
\hline b. Hypofibrinogenemia & $D A * *$ & $D A^{* *}$ \\
\hline c. Hyponatremia & $D A * *$ & $D A^{* *}$ \\
\hline
\end{tabular}

*Diagnostic guidelines for $\mathrm{HLH}^{6} ; * *$ DA: data absence.

Source: Research Data.

On the third day of admission (DA), P1 had leukopenia with left shift and decreased blood counts. The patient was prostrated, pale, and presented mild jaundice and lower limb edema. On the fifth DA, the patient had a $40{ }^{\circ} \mathrm{C}$ fever, pain in the legs, hematuria, and pancytopenia. In the physical examination, $\mathrm{P} 1$ was dehydrated $(4+/ 4+)$ and icteric $(4+/ 4+)$.

On the sixth DA, P1 had diffused abdominal pain, hepatosplenomegaly, pancytopenia, and adynamia. On that day, there was suspicion of chronic myelogenous leukemia and pancreatic neoplasia. The patient progressed to acute renal failure. Bone marrow cytology was requested to investigate fungi and neoplastic cells. Laboratory tests showed worsening of anemia and leukopenia. Antibiotic therapy was started.

On the seventh DA, the fever persisted and the patient was apathetic, dyspneic and very quiet. The bone marrow aspirate culture was negative. An acute gastroduodenitis with signs of recent bleeding was observed in the endoscopy examination. On the eighth DA, the patient evolved into mental confusion. The serological tests were negative for Trypanosoma cruzi, hepatitis B core antibody (anti-HBc) and hepatitis B surface antigen (HBsAg), and positive for the hepatitis $\mathrm{C}$ virus (HCV).

From the ninth to the $12^{\text {th }}$ DA patient has worsened clinically and presented spontaneous emetic episodes and hepatic cholestasis. P1 persisted with pancytopenia, dyspnea $(1+/ 4+)$, pallor $(2+/ 4+)$, jaundice $(4+/ 4+)$, fever, and did not respond to verbal commands. On the $13^{\text {th }}$ DA was suggested exploratory laparotomy. However, on the $14^{\text {th }}$ DA, due to clinical worsening, abnormal breathing pattern, and hypothermia, there were no surgical conditions.

On the $15^{\text {th }} \mathrm{DA}$, the patient was lethargic, but he opened his eyes on command; presented dyspnea and hypersecretion, and received continuous nebulization. On the $16^{\text {th }} \mathrm{DA}$, the patient had edema in the hands and feet, bleeding in the penile region, low oxygen saturation and a low heart rate, and then evolving to death.

\subsection{Analysis of the organs by autopsy of P1}

The autopsy showed acute hepatitis with necrosis, and inflammatory infiltrate predominantly constituted by lymphocytes and plasma cells in the portal space. There was macrovesicular steatosis, and perivascular fibrosis with several macrophages containing red blood cells. Mild hepatic cholestasis, and severe hepatomegaly (weight: $2550 \mathrm{~g}$ ) were observed. The lymph nodes in the hepatic hilum were enlarged and had fewer lymphoid follicles. There was sinus histiocytosis with histiocytes containing red blood cells.

The spleen had a homogeneous, smooth, glistening, dark reddish brown appearance and splenomegaly (weight: 1050 g). The microscopic analysis showed lymphocytes depletion in the germinal center of the lymphoid follicle, hemorrhage, and changes in splenic architecture. In the red splenic pulp, plasmacytic infiltrate and an intense quantity of mononuclear leukocytes, especially macrophages, were observed. There were several red blood cells in the macrophages cytoplasm (Figure 1E).

The bone marrow was hypercellular, with a high number of macrophages. Many macrophages also contained red blood cells inside. Erythrocytes were decreased whereas granulocytes and megakaryocytes were normal. The autopsy report suggested $\mathrm{HLH}$, because there was hemophagocytosis in macrophages located in the liver, spleen, lymph nodes and bone marrow.

\subsection{Clinical evolution and laboratory findings of P2}

An 18-year-old male patient was admitted to the hospital complaining of severe diffuse colicky abdominal pain for two days with fever peaks (not measured), sweating and chills for 24 hours. At the physical examination, P2 was lethargic, tachypneic, icteric $(1+/ 4+)$, pale $(3+/ 4+)$, hydrated, with a temperature of $37.1^{\circ} \mathrm{C}$ and presented diffuse petechiae. There was suspicion of systemic inflammatory response syndrome due to the intra-abdominal focus of infection, severe hemolytic anemia, hemolytic jaundice, and respiratory failure.

On the second DA, P2 was dehydrated $(+2 /+4)$, cyanotic, and had respiratory failure, so he underwent orotracheal intubation with mechanical ventilation $\left(70 \% \mathrm{O}_{2}\right.$, saturation 96-100\%) and continuous sedation with Dormonid $10 \mathrm{ml} / \mathrm{h}$ under cardiac monitoring. Hepatosplenomegaly was observed in abdominal computed tomography (CT). The direct Coombs test was negative. In the myelogram, the bone marrow was hyperplasic, with increased red blood cell count and macrophage activity, but decreased white blood cell count. On the third DA, the patient had eyelid edema, vomiting and a $38.8^{\circ} \mathrm{C}$ fever. The dose of Dormonid was increased to $25 \mathrm{ml} / \mathrm{h}$. On the fourth $\mathrm{DA}$, the patient presented anasarca, 
abdominal distension, generalized petechiae, and signs of nasal and oral bleeding. The patient suffered cardiorespiratory arrest evolving to death.

\subsection{Analysis of the organs by autopsy of P2}

The patient had bilateral bronchopneumonia and acute tubular necrosis. Generalized hemorrhage was observed at autopsy: gingival bleeding, conjunctival hemorrhage, petechiae diffusely distributed over the skin and serosal membranes (mainly pleura and pericardium), hemorrhage and ulceration of the esophageal and gastric mucosa, myocardium hemorrhage, hemorrhagic cystitis, bilateral adrenal hemorrhage, and subarachnoid hemorrhage measuring $2 \times 3 \mathrm{~cm}$ in the left temporal lobe. Furthermore, the patient had DIC and anasarca. Hemocatheresis, steatosis, moderate mononuclear infiltrate and perivascular fibrosis were observed in the liver (weight: $1008 \mathrm{~g}$ ), whereas hemosiderin, hemophagocytosis, destruction of the splenic architecture and splenomegaly (weight: $250 \mathrm{~g}$ ) were observed in the spleen.

\subsection{Immunohistochemical evaluation of CD68 and CD57 in the liver and spleen of P1 and P2}

Immunostaining in the liver and spleen of both patients was predominantly severe for CD68, and predominantly mild for CD57 (Table 2, Figure 1A, 1B, 1C, 1D).

Table 2 - Pathological processes and immunostaining for CD68 and CD57 in spleen and liver of both patients (P1 and P2)

\begin{tabular}{|l|c|c|}
\hline $\begin{array}{l}\text { Pathological processes/ } \\
\text { Immunostaining }\end{array}$ & Spleen & Liver \\
\hline Hemorrhage & P1 & - \\
\hline Hyperplasia & P1 & - \\
\hline Hepatic steatosis & - & P1 \\
\hline Fibrosis & - & P1 \\
\hline Inflammation & - & P1 \\
\hline Hemosiderin & P2 & - \\
\hline Immunostaining for CD68 (P1) & Moderate & Severe \\
\hline Immunostaining for CD68 (P2) & Severe & Severe \\
\hline Immunostaining for CD57 (P1) & Mild & Mild \\
\hline Immunostaining for CD57 (P2) & Severe & Mild \\
\hline
\end{tabular}

(-) indicates absence.

Source: Research Data.

Figure 1 - Histopathological and immunohistochemical findings of liver and spleen of both patients

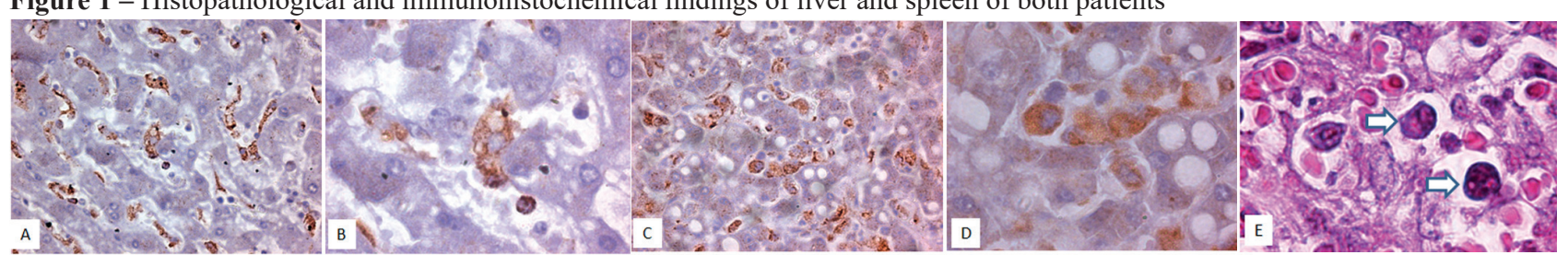

Cells immunostained by anti-CD68 in the liver (P2) (immunohistochemistry, 40X); (B) Detail of figure A (immunohistochemistry, 100X); (C) Cells immunostained by anti-CD-57 in the liver (P1) (immunohistochemistry, 40X); (D) Detail of figure C (immunohistochemistry, 100X); (E) Macrophages with hemophagocytosis in the spleen (P1) (arrows) (HE, 100X).

Source: The Authors.

The results of the histochemical and immunohistochemical analyses were compared to the clinical and laboratory data described in the patients' medical records and to the autopsy reports.

It is known that for the correct diagnosis of HLH the following diagnostic criteria must be met: molecular diagnosis of hemophagocytic lymphohistiocytosis (HLH) or X-linked lymphoproliferative syndrome (XLP) or (a) fever, splenomegaly, cytopenias (minimum of 2 cell lines reduced), and hepatitis (at least 3 of 4); and (b) hemophagocytosis, elevated levels of ferritin, elevated levels of soluble IL2R $\alpha$, and absent or very decreased NK function (at least 1 of 4). ${ }^{6}$ Thus, both patients in the present study not only fulfilled the criteria for HLH, but also presented common symptoms of HLH, such as chills, abdominal pain, diaphoresis, and jaundice. However, there has not been any suspicion of HLH during hospitalization, so they rapidly evolved to death.

Infection represents the most common underlying condition in secondary HLH. ${ }^{8,18,21}$ In the present study, P1 had acute hepatitis probably associated with $\mathrm{HCV}$, and P2 had bronchopneumonia and DIC. As these patients were adults and had no family history of HLH, we concluded that they presented the secondary form of HLH, associated with infectious conditions.

It has been reported that patients with HLH often present hepatomegaly, ${ }^{1,4,22}$ which was observed on clinical examination and at autopsy of P1. The hepatomegaly probably occurred due to the proliferation of macrophages, as shown in the microscopic analysis of this organ. On the other hand, it is known that splenomegaly and increased number of macrophages are commonly seen in patients with HLH. ${ }^{22,23}$ In the present study, the increased number of macrophages could also have caused the splenomegaly observed in both patients.

Sudden and persistent fever is one of the most frequent clinical manifestations of $\mathrm{HLH}^{4,8,18,24}$. In the present study, P1 and $\mathrm{P} 2$ had a persistent high fever. The cause of the onset and persistence of fever may be the production of endogenous pyrogens TNF- $\alpha$ and IL- $1,,^{8,23,25}$ which would be increased because of the infectious conditions presented by both patients.

It is known that patients with HLH may present jaundice, ${ }^{1,4,26}$ hence corroborating our findings since both patients were icteric. Jaundice occurs due to the impregnation of bilirubin in different tissues in consequence of hyperbilirubinemia, ${ }^{27}$ which was also observed in both patients of the present 
study. The hyperbilirubinemia can be caused by pre-hepatic factors, such as increased hemolysis; by hepatic factors, such as decreased liver function; and by post-hepatic factors, such as liver fibrosis. ${ }^{28}$ In the present study, jaundice was probably caused by several reasons: (1) increased bilirubin production, which probably happened due to intense red blood cells phagocytosis (in P1 and P2); (2) decreased bilirubin uptake by sepsis (in P2); (3) decreased conjugation with glucuronic acid due to hepatic lesions; and (4) impaired excretion of bilirubin in consequence of periductal fibrosis.

Studies have shown that patients with HLH may have edema. $^{10}$ In the present study, both patients presented edema, probably due to inflammation and decreased protein synthesis subsequent to hepatic injury. In addition, P1 presented hyponatremia which could be contributing to the edema. ${ }^{29}$ Furthermore, patients with HLH may present lymphadenopathy. ${ }^{3,10,22-27}$ In the present study, lymphadenopathy was observed in $\mathrm{P} 1$, probably due to the excessive proliferation of $\mathrm{T}$ cells and histiocytes in the lymph nodes, which is typical of $\mathrm{HLH},{ }^{23}$ and also due to a redirection of these cells to the lymph nodes after tissue inflammatory reaction..$^{23,30}$

It has already been described that the most relevant characteristic in HLH is a large number of macrophages phagocytizing hematopoietic cells in the bone marrow. ${ }^{5,31}$ In the early stage of the disease, the bone marrow is generally hypercellular and contains few infiltrates of histiocytes. In the late phase, the bone marrow is hypocellular and contains several histiocytic infiltrates. ${ }^{32}$ In the present study, P1 bone marrow was hypercellular and contained several macrophages phagocytizing red blood cells, which led to a decrease in red blood cell counts. Thus, we believe that $\mathrm{P} 1$ would be in the early stage of the disease and so have not died as quickly as P2.

Hypertriglyceridemia ${ }^{24,33,34}$ and hyperferritinemia ${ }^{1,29}$ are commonly found in HLH. The hypertriglyceridemia occurs probably due to increased lipolytic activity induced by cytokines such as IL-1 and TNF. ${ }^{15,31}$ Even though no tests were performed to assess triglyceride levels in the patients, both P1 and P2 had hepatic steatosis. Therefore, high levels of circulating triglyceride could have caused hepatic steatosis observed in both patients as a result of the increased levels of IL-1 and TGF released during infectious conditions. ${ }^{35}$ On the other hand, the hyperferritinemia occurs due to the accumulation of ferritin in macrophages during erythrophagocytosis and due to the increase in its interleukinmediated synthesis. ${ }^{30}$ Nevertheless, none of the cases described in the present study reported ferritin doses, probably because there was no suspicion of HLH.

Anemia is a frequent finding in $\mathrm{HLH}^{23,24,33,36}$ being caused by erythrophagocytosis and enhanced by the inflammatory state. ${ }^{32}$ In the present study, both P1 and P2 had severe anemia and increased levels of lactate dehydrogenase (LDH).
Patients with HLH may have poor prognostic factors, such as neurological changes, renal disorders, hepatic failure, or hemorrhagic diathesis. ${ }^{4,22,37}$ In our study, P1 had neurological changes and renal dysfunction (acute tubular necrosis). The $\mathrm{P} 2$ has also had the same renal dysfunction as well as hemorrhagic diathesis. Therefore, these complications may have contributed to the rapid evolution to death in both patients.

The CD68 immunostaining was predominantly severe in the spleen and liver of both patients, corroborating the histochemical analysis, which showed a large number of macrophages in these organs. Activated CD8+ T cells can produce large amounts of IFN that stimulates the proliferation and activation of macrophages, justifying the higher number of macrophages immunostained by CD68 in the present study. Although CD68 immunostaining in organs of autopsied children with primary HLH has been already demonstrated, ${ }^{38-40}$ we did not find any study that evaluated this marker in the adult with secondary form of HLH through autopsies.

On the other hand, the CD57 immunostaining was predominantly mild in the spleen and liver of both patients, showing a small number of NKC in these sites. The evaluation of CD57 in HLH was performed in a few studies, but only in the serum of patients. ${ }^{19,20}$ The mild CD57 immunostaining would indicate that not only the cytotoxic activity of NKC would be decreased ${ }^{41}$ but also the number of these cells.

\section{Conclusion}

Therefore, the histochemical, immunohistochemical and pathophysiological aspects of the two cases were compatible with HLH. However, the diagnosis was made only after the autopsies, probably because this disease is rare and littleknown by clinicians. The mild CD57 and severe CD68 immunostaining indicate a decrease in NKC numbers and an increase in the number of macrophages, respectively. This was the first study to evaluate CD57 and CD68 in autopsies of adults with HLH. Thus, more studies are required, not only to better elucidate the pathogenetic mechanisms involved in the secondary HLH, but also to disseminate the results in the clinical environment, contributing to the early diagnosis and treatment with consequent reduction of mortality rate.

\section{Acknowledgements}

University of Uberaba (UNIUBE), the Center for Professional Education (CEFORES) of the Federal University of Triangulo Mineiro (UFTM), Postgraduate Program in Health Sciences of the Federal University of the Triangulo Mineiro (UFTM), National Counsel of Technological and Scientific Development (CNPq), Coordination of Improvement of Higher Education Personnel (CAPES), and Minas Gerais State Research Foundation (FAPEMIG). 


\section{References}

1. Mostaza-Fernández JL, Guerra Laso J, Carriedo Ule D, Ruiz de Morales JM. Hemophagocytic lymphohistiocytosis associated with viral infections: diagnostic challenge and therapeutic dilemma. Rev Clin Esp 2014;214(6):320-7. doi: 10.1016/j.rce.2014.03.009

2. Brito-Zerón P, Kostov B, Moral-Moral P, MartínezZapico A, Díaz-Pedroche C, Fraile G, et al. Prognostic Factors of Death in 151 Adults With Hemophagocytic Syndrome: Etiopathogenically Driven Analysis. Mayo Clin Proc Inn Qual Out 2018;2(3):267-76. doi: 10.1016/j. mayocpiqo.2018.06.006

3. Biank VF, Sheth MK, Talano J, Margolis D, Simpson P, Kugathasan S, et al. Association of Crohn's disease, thiopurines, and primary epstein-barr virus infection with hemophagocytic lymphohistiocytosis. J Pediatr 2011;159(5):808-12. doi: 10.1016/j.jpeds.2011.04.045

4. Bordbar MR, Modarrezi F, Farazi Fard MA, Dastsooz H, Shakib Azad N, Faghihi MA. A case report of novel mutation in PRF1 gene, which causes familial autosomal recessive hemophagocytic lymphohistiocytosis. BMC Med Genet 2017;18(1):49. doi: 10.1186/s12881-017-0404-9

5. Brandão-Neto RA, Santana AN, Danilovic DLS, Bernardi FDC. A very rare cause of dyspnea with a unique presentation on a computed tomography scan of the chest: macrophage activation syndrome. J Bras Pneumol 2008;34(2):118-20. doi: 10.1590/s1806-37132008000200009

6. Filipovich AH. Hemophagocytic lymphohistiocytosis (HLH) and related disorders. Hematology 2009(1):127-31. doi: 10.1182/asheducation-2009.1.127

7. Tesi B, Bryceson YT. HLH: genomics illuminates pathophysiological diversity. Blood 2018;132(1):5-7. doi: 10.1182/blood-2018-05-845818

8. Janka GE, Lehmberg K. Hemophagocytic syndromes: an update. Blood Rev 2014;28(4):135-42. doi: 10.1016/j. blre.2014.03.002

9. Atteritano M, David A, Bagnato G, Beninati C, Frisina A, Iaria $\mathrm{C}$, et al. Haemophagocytic syndrome in rheumatic patients. a systematic review. Eur Rev Med Pharmacol Sci 2012;16(10):1414-24.

10. Poddighe D, Cavagna L, Brazzelli V, Bruni P, Marseglia GL. A hyper-ferritinemia syndrome evolving in recurrent macrophage activation syndrome, as an onset of amyopathic juvenile dermatomyositis: a challenging clinical case in light of the current diagnostic criteria. Autoimmun Rev 2014;13(11):1142-8. doi: 10.1016/j.autrev.2014.05.009

11. Ishii E. Hemophagocytic lymphohistiocytosis in children: pathogenesis and treatment. Front Pediatr. 2016;4:47. doi: 10.3389/fped.2016.00047

12. Ravelli A. Macrophage activation syndrome. Curr Opin Rheumatol 2002;14(5):548-52. doi: 10.1097/00002281200209000-00012

13. Grom AA. Macrophage activation syndrome and reactive hemophagocytic lymphohistiocytosis: the same entities? Curr Opin Rheumatol 2003;15(5):587-90. doi: 10.1097/00002281200309000-00011

14. Morimoto A, Nakazawa Y, Ishii E. Hemophagocytic lymphohistiocytosis: Pathogenesis, diagnosis, and management. Pediatr Int 2016;58(9):817-25. doi: 10.1111/ ped.13064

15. Crayne CB, Albeituni S, Nichols KE, Cron RQ. The immunology of Macrophage Activation Syndrome. Front Immunol 2019;119(10):1-11. doi: 10.3389/fimmu.2019.00119

16. Hasselblom S, Linde A, Ridell B. Hodgkin's lymphoma, Epstein-Barr virus reactivation and fatal haemophagocytic syndrome. Curr Opin Rheumatol 2004;255(2):289-95. doi: 10.1046/j.0954-6820.2003.01249.x

17. Todaro J, Bollman PW, Heymann RE, Peres MFP, Santana Netto PV, Felix MM, et al. Hemophagocytic syndrome in a patient with marginal zone lymphoma and Sjögren's syndrome. RBM 2013;70(1):7-10.

18. Amisha, Malik P, Pathania M, Rathaur VK, Kaeley N. Hemophagocytic lymphohistiocytosis as a diagnostic consideration of fever of unknown origin with pancytopenia and chronic liver disease. J Family Med Prim Care 2019;8(4):1504-1507. doi: 10.4103/jfmpc.jfmpc_190_19

19. Chiang SC, Theorell J, Entesarian M, Meeths M, Mastafa M, Al-Herz W, et al. Comparison of primary human cytotoxic T-cell and natural killer cell responses reveal similar molecular requirements for lytic granule exocytosis but differences in cytokine production. Blood 2013;121(8):134556. doi: 10.1182/blood-2012-07-442558

20. Ammann S, Lehmberg K, Zur Stadt U, Janka G, Rensing-Ehl A, Klemann C, et al. Primary and secondary hemophagocytic lymphohistiocytosis have different patterns of T-cell activation, differentiation and repertoire. Eur $\mathrm{J}$ Immunol 2017;47(2):364-73. doi: 10.1002/eji.201646686.

21. Fatima Z, Khan A, Tariq U, Sohail MS. Hemophagocytic lymphohistiocytosis: a case series. Cereus 2018;10(4): e2545. doi: 10.7759 /cureus. 2545

22. Ravelli A, Magni-Manzoni S, Pistorio A, Besana C, Foti $\mathrm{T}$, Ruperto N, et al. Preliminary diagnostic guidelines for macrophage activation syndrome complicating systemic juvenile idiopathic arthritis. J Pediatr 2005;146(5):598-604. doi: 10.1016/j.jpeds.2004.12.016.

23. Prado R, Terreri MT, Len CA, Braga J, Hilário MO. Macrophage activation syndrome in patients with juvenile idiopathic arthritis. Rev Bras Reumatol 2004;44(5):378-82. doi: $10.1590 / \mathrm{S} 0482-50042004000500012$

24. Silva CAA, Silva CHM, Robazzi TCMV, Lolito APN, Mendroni Junior A, Jacob CMA, et al. Macrophage activation syndrome associated with systemic juvenile idiopathic arthritis. J Pediatr 2004;80(6):517-22. doi: 10.2223/ JPED. 1267

25. Janka GE. Hemophagocytic syndromes. Blood Rev 2007;21(5):245-53. doi: 10.1016/j.blre.2007.05.001

26. Lufti F, Patel A, Becker D, Shahid M, Shah K. Hemophagocytic lymphohistiocytosis (HLH) presenting as fever of unknown origin and acute liver failure. IDcases 2018;14: e00413. doi: 10.1016/j.idcr.2018.e00413

27. Abbas MW, Shamshad T, Ashraf MA, Javaid R. Jaundice: a basic review. Int J Res Med Sci. 2016;4(5):1313-9. doi: 10.18203/2320-6012.ijrms20161196

28. Dupas B, Gournay J, Frampas E, Leaute F, Le Borgne J. Anicteric cholestasis: imaging and diagnostic strategy. J Radiol 2006;87(4 Pt2):441-59. doi: 10.1016/s02210363(06)74026-4

29. Salah K, Kok WE, Eurlings LW, Bettencourt P, Pimenta $\mathrm{JM}$, Metra $\mathrm{M}$, et al. A novel discharge risk model for patients hospitalised for acute decompensated heart failure incorporating $\mathrm{N}$-terminal pro-B-type natriuretic peptide levels: a european collaboration on acute decompensated heart failure: ELAN-HF score. Heart 2014;100(2):115-25. 
doi: 10.1136/heartjnl-2013-303632

30. Cavalcante MHL, Miná AAL. Hepatosplenomegaly. It's not always kala-azar. Rev. Saúde Criança Adolesc 2011;3(1):705 .

31. Ronchi Júnior I, Pietrovicz J, Nocera VB, Vasconcelos CN, Fouani, MM, Pedri, LE. Hemaphagocytic syndrome. case report. Rev Bras Clin Med 2011;9(5):382-8.

32. Kuczynski AP, Cantergiani HB, Saraiva Junior JD. Síndrome hemofagocítica secundária [Secondary hemophagocytic syndrome]. Pediatria 1998;20(2):142-5.

33. Vega J, Rodríguez Mde L, Goecke H, Santamarina M. Hemophagocytic syndrome after dney transplant in a patient with hereditary nephritis. Report of one case. Rev Med Chil 2013;141(4):519-24. doi: 10.4067/S003498872013000400014

34. Schettert IT, Cardinalli IA, Ozello MC, Vassalo J, LorandMetze I, Souza CA. Hemophagocytic syndrome: pitfalls in its diagnosis. Sao Paulo Med J 1997;115(5):1548-52. doi: 10.1590/S1516-31801997000500007

35. Meng Z, Zhang Y, Wei Z, Liu P, Kang J, Zhang Y, et al. High serum resistin associates with intrahepatic inflammation and necrosis: an index of disease severity for patients with chronic HBV infection. BMC Gastroenterol 2017;17(1):6. doi: 10.1186/s12876-016-0558-5
36. Tuon FF, Gomes VS, Amato VS, Graf ME, Fonseca GHH, Lazari C, et al. Hemophagocytic syndrome associated with hepatitis A: case report and literature review. Rev Inst Med Trop 2008;50(2):123-7. doi: 10.1590/S003646652008000200012

37. Izzedine H, Brocheriou I, Martinez V, Camous L, Guillemont MC, Deray G. Fever, nephrotic syndrome, and rapidly progressive renal failure. Kidney Int 2007;72(5):651-6. doi: 10.1038/sj.ki.5002298

38. Parizhskaya M, Reyes J, Jaffe R. Hemophagocytic syndrome presenting as acute hepatic failure in two infants: clinical overlap with neonatal hemochromatosis. Pediatr Dev Pathol 1999;2(4):360-6.

39. Chen JH, Fleming MD, Pinkus GS, Pinkus JL, Nichols KE, Mo JQ, et al. Pathology of the liver in familial hemophagocytic lymphohistiocytosis. Am J Surg Pathol 2010;34(6):852-67. doi: 10.1097/PAS.0b013e3181dbbb17

40. Mu J, Jin C, Chen Z, Li J. Fatal unexpected death due to familial hemophagocytic lymphohistiocytosis type 3 . Forensic Sci Med Pathol 2018;14(3)372-6. doi: 10.1007/ s12024-018-9986-6

41. Semberova J, Rychly B, Hanzelova J, Jakubikova J. The immune status in situ of recurrent tonsillitis and idiopathic tonsillar hypertrophy. Bratisl Lek Listy 2013;114(3):140-4. 